syjną. Te dwa zjawiska składają się na problem relokacji źródeł energii, który w szczególny sposób dotyczy opartej na węglu polskiej energetyki. Jako najbardziej prawdopodobny scenariusz wskazuje się import energii elektrycznej z Litwy i Ukrainy, z elektrowni jądrowych Ignalina i Chmielnicka oraz elektrowni wodnych.

Końcowy element analizy stanowi ocena możliwości wykorzystania przez Polskę czternastoprocentowego wzrostu emisji gazów cieplarnianych do roku $2020 \mathrm{w}$ sektorach, które nie zostały objęte systemem EU ETS. Bolesław Jankowski, uwzględniając bazowy i umiarkowany scenariusz makroekonomiczny, przedstawia prognozę popytu na energię w sektorach non ETS oraz emisji dwutlenku węgla z procesów produkcyjnych i pozostałych źródeł (produkty mineralne, przemysł chemiczny, produkcja metali, inne).

W omawianej publikacji zaprezentowano szerokie spektrum zagadnień, szczególną uwagę poświęcając jednak przeanalizowaniu wpływu pakietu na strukturę zaopatrzenia Polski w energię oraz bezpieczeństwa energetycznego, redukcji emisji dwutlenku węgla, wpływu pakietu na konkurencyjność branż energochłonnych oraz samego sektora elektroenergetycznego. Szczegółowej analizie poddano także metody alokacji uprawnień do emisji.

MARTA ZOBENIAK Poznań

\title{
Misje cywilne Unii Europejskiej, red. Beata Przybylska-Maszner, Wydawnictwo Naukowe WNPiD UAM, Poznań 2010, ss. 312.
}

Publikacja pt. Misje cywilne Unii Europejskiej, została wydana pod redakcją Beaty Przybylskiej-Maszner, przez Wydawnictwo Naukowe Wydziału Nauk Politycznych i Dziennikarstwa UAM. Dotyka szerokiego i istotnego współcześnie obszaru działań zewnętrznych UE, w ramach tzw. Wspólnej Polityki Zagranicznej i Bezpieczeństwa. We wprowadzeniu do książki, stwierdzone zostało nawet, że owo ,zaangażowanie operacyjne jest najważniejszym przejawem skuteczności Unii na arenie międzynarodowej" ${ }^{\prime \prime}$. Sama praca została podzielona na siedem zróżnicowanych tematycznie rozdziałów, skupiających w sobie artykuły aż szesnastu autorów. Indywidualne podejście każdego z autorów do problematyki z zakresu misji cywilnych UE, idealnie oddaje skomplikowaną charakterystykę wyzwań, przed jakimi został postawiony personel poszczególnych operacji. Książka obok stworzenia niejako mapy aktywności w zakresie misji cywilnych poza granicami UE, jest niewątpliwie niezmiernie ważnym głosem w dyskusji nad ich skutecznością oraz przyszłością tego rodzaju działań.

Pierwszy rozdział porusza problematykę procesu kształtowania się zdolności operacyjnych UE w zakresie wspólnej polityki bezpieczeństwa i obrony. Jego autor - Zbigniew Czachór, przybliżył czytelnikowi historię tworzenia kluczowych podstaw prawnych dla funkcjonowania misji poza granicami UE, o których jest mowa w dalszych rozdziałach publikacji. Jednocześnie wskazał na najważniejsze wyzwania stojące przed UE, w obliczu tzw. Europejskiej Strategii Bezpieczeństwa, do których zaliczone zostały m.in. proliferacja broni masowego rażenia, rozwój terroryzmu i przestępczości zorganizowanej, ale także kwestie współczesnego cyberterroryzmu coraz częściej zagrażającego rozwiniętym państwom świata czy też bezpieczeństwa energetycznego. Niezmiernie ciekawym elementem rozdziału jest zarysowanie przez autora zdolności operacyjnych UE, w kontekście Traktatu z Lizbony. Przeprowadzona analiza przedstawia w sposób bardzo czytelny drogę ku rozszerzeniu zakresu możliwości oddziaływania UE w sytuacjach kryzysowych, od trak-

1 B. Przybylska-Maszner, Wprowadzenie, w: Misje cywilne Unii Europejskiej, red. B. Przybylska-Maszner, Poznań 2010, s. 7. 
tatu z Maastricht, aż do dnia dzisiejszego. Autor jednoznacznie podkreśla, wyprowadzając wnioski do swych rozważań, że ,jeżeli Unia Europejska dąży do odgrywania samodzielnej roli w skali świata, musi być gotowa do podejmowania operacji o dużym stopniu trudności, wymagających zaangażowania poważnych sił i wiążących się z podwyższonym ryzykiem strat"”2.

Drugi rozdział publikacji został poświęcony studiom trzech przypadków zastosowania środków unijnych do wspierania procesu budowy państwa prawnego w państwach, które są targane problemami natury wewnętrznej, jak i zewnętrznej. Pierwszy artykuł, którego autorem jest Łukasz Donaj, przybliżył zakres misji EUJUST THEMIS w Gruzji. Na wstępie wskazane zostało tło historyczne przemian demokratycznych w Gruzji, nazwanych „rewolucją róż”, po czym autor odniósł się do najważniejszych podstaw prawnych misji UE oraz zaprezentował cele i strukturę misji EUJUST THEMIS. Z racji, że misja została zakończona, autor mógł dokonać głębokiej analizy podjętych działań, zestawiając ze sobą oczekiwania i realia. Wynikiem jest duża doza krytycyzmu wobec funkcjonowania misji gruzińskiej. Ł. Donaj napisał, iż „biorąc pod uwagę fakt, że UE stara się być liczącym aktorem stosunków międzynarodowych, nie może sobie pozwalać li tylko na «półśrodki», jak EUJUST THEMIS"”. Drugim artykułem, zawartym w rozdziale poświęconym misjom UE dotyczącym kwestii państwa prawnego, jest analiza pt. EUJUST LEX -zintegrowana misja Unii Europejskiej w Iraku dotyczqca państwa prawnego. Jego autorka, Magdalena Lorenc, bardzo szeroko omówiła praktykę funkcjonowania misji irackiej UE. Cennym elementem analizy było wprowadzenie m.in. bardzo przejrzystego schematu organizacyjnego oraz odwołanie się do opinii formułowanych przez pierwszego szefa misji EUJUST LEX Stephena White, pomocnych w ocenie zaangażowania UE w Iraku. Trzeci z autorów drugiego rozdziału książki, Tomasz Brańka, skupił swe rozważania na misji EULEX w Kosowie, dotykając $\mathrm{w}$ ten sposób kwestii jednego $\mathrm{z}$ najbardziej newralgicznych punktów zapalnych na kontynencie europejskim. Należy podkreślić fakt, że autor omawiając funkcjonowanie i strukturę EULEX, nie obawiał się zaprezentować także wątpliwości, jakie niesie ze sobą samo funkejonowanie Kosowa w formie niepodległego państwa, nie tylko dla samego bezpieczeństwa wewnętrznego Kosowa, ale i reszty społeczności międzynarodowej. Autor z dużą dozą ostrożności i krytycyzmu podszedł także do ferowania oceny skuteczności działań UE w ramach EULEX Kosowo. Szczególnie, że jak podkreślił „,nie jest możliwym pełna ocena efektywności i działań misji ze względu na fakt, iż misja ta nie została jeszcze zakończona"4.

Rozdział trzeci książki został zbudowany w oparciu o studia przypadków opisujących misje obserwacyjne Unii Europejskiej w wybranych, zapalnych rejonach na świecie. W tym przypadku, dzięki umiejętnie prezentowanej bezstronności w konkretnych sporach UE może wychodzić z pozycji rozjemcy dla zwaśnionych stron konfliktów. Pierwszy artykuł rozdziału, napisany przez Łukasza Donaja, odniósł się do jakże ważnej dla całej szeroko pojmowanej polityki wschodniej UE, kwestii wojny w Gruzji z 2008 r. Autor obok zarysowania tla konfliktu w Osetii Południowej i Abchazji, czytelnie opisał strukturę i organizację misji obserwacyjnej UE. Jednak wydaje się, że najistotniejsze było zaprezentowanie trudnych i skomplikowanych warunków wykonywania działań w ramach EUMM w Gruzji, szczególnie w kontekście spornej kwestii uznania przez Federację Rosyjską niepodległości Osetii Południowej i Abchazji. Ciekawym zabiegiem autora było także wprowadzenie na końcu artykułu załącznika, w którym zawarte zostało kalendarium najważniejszych wydarzeń konfliktu gruzińsko-rosyjskiego. Drugą misją obserwacyjną UE, omawianą w rozdziale są działania podjęte na rzecz zapewnienia spokoju w indonezyjskiej prowincji Aceh. Autor, Przemysław Osiewicz, przedstawił więc zarys proble-

2 Z. Czachór, Proces ksztaltowania zdolności operacyjnych Unii Europejskiej w obszarze Wspólnej Polityki Bezpieczeństwa i Obrony, w: Ibidem, s. 28.

3 Ł. Donaj, Rzady Prawa i EUJUST THEMIS pośród gruzińskich róż, w: Ibidem, s. 41.

4 T. Brańka, EULEX Kosowo - największa misja cywilna, w: Ibidem, s. 80. 
matyki konfliktu w Aceh i okoliczności, w jakich UE zdecydowała się podjąć działania w tym odległym od Europy zakątku świata. Autor podkreślił, że „,misja obserwacyjna w Aceh stała się jednym z elementów zacieśniania współpracy pomiędzy Unią Europejską a Stowarzyszeniem Narodów Azji Południowo-Wschodniej"s. Wykazując, że nawet zwyczajowa aktywność w zakresie misji obserwacyjnych może stać się przyczynkiem do rozbudowy pozycji zjednoczonej Europy w różnych regionach świata, nawet tych, w których dotychczas nie prowadzone były na tak szeroką skalę działania UE. Jednocześnie autor zauważa, że misja w Aceh zakończyła się sukcesem i stanowi udany przykład misji cywilnej. W przeciwieństwie do sukcesu w Aceh, ostatni artykuł zamieszczony w omawianym rozdziale, poruszył bolesną kwestię aktywności unijnej w regionie Zachodnich Bałkanów. Jego autor, Witold Ostant, odniósł się do problemu rozpadu Jugosławii i wynikłych z tego faktu konfliktów zbrojnych, wprowadzając na ich tle opis prób działań podejmowanych w ramach misji ECMM i EUMM. Ważnym zabiegiem było przedstawienie, wraz z rozwojem wydarzeń w spornym regionie Bałkanów, transformacji samej integrującej się Europy. Czytelnik może także zaznajomić się z konstrukcją misji obserwacyjnej korzystając z załączonych do artykułu schematów organizacyjnych. Jako dobrą naukę dla przyszłych misji UE na świecie, należy rozważyć ocenę autora, który stwierdził, że „analizując słabości i silne cechy ECMM należy zwrócić uwagę, iż połączenie cech dyplomatycznej misji z elastycznością quasi wojskowej organizacji miało tyle samo zalet co wad. Misja pomimo swych zalet, nie wpłynęła znacząco na zbudowanie trwałego pokoju, zabrakło sił, środków i woli politycznej oraz realnej siły zbrojnej, które w swej gestii WE, a następnie UE nie posiadały”6.

Rozdział czwarty publikacji został poświęcony misjom UE służącym reformom sektora bezpieczeństwa w wybranych państwach świata. Beata Przybylska-Maszner przybliżyła w swym artykule misję EUSEC, w Demokratycznej Republice Konga, podkreślając, iż ,wysiłki państw członkowskich zaangażowanych w misję w oparciu o zasoby UE, mogą przyczynić się nie tylko do poprawy sytuacji w DRK, ale mieć wpływ na umocnienie stabilności w regionie Wielkich Jezior Afrykańskich", . W sposób bardzo interesujący dla czytelnika autorka zaprezentowała etapy misji, umieszczając w swym artykule zbudowaną przez siebie tabelę prezentującą podstawy prawne misji, ich czas obowiązywania, a także dokonując streszczenia najważniejszych zadań umieszczonych w mandacie misji. Podobnie, również w postaci tabeli, zostały zaprezentowane kompetencje w zakresie kontroli politycznej i kierownictwa strategicznego EUSEC Congo, co ułatwia zrozumienie skomplikowanych relacji występujących pomiędzy różnymi centrami decyzyjnymi odpowiadającymi za funkcjonowanie całej misji. Drugi artykuł zamieszczony w omawianym rozdziale pracy, autorstwa Michała Luszczuka, poświęcony został może mniej znanej niż ta w Kongo, misji UE w Republice Gwinei Bissau. Prowadzone tam działania również skupiły się na reformie sektora bezpieczeństwa tego afrykańskiego państwa. Autor zaprezentował całą strukturę misji. Wyprowadzając zaś wstępne wnioski, bowiem operacja nie została zakończona, ocenił wielce krytycznie jej dotychczasowe funkcjonowanie. Czytelnie wypunktowane zostały słabe strony działań podjętych w Republice Gwinei Bissau. Pojawiło się stwierdzenie, że ,ambitne plany były więc chyba bardziej wyrazem dobrych chęci UE niż realnej oceny jej możliwości i obiektywnych uwarunkowań",

5 P. Osiewicz, Misja obserwacyjna Unii Europejskiej w Aceh (AMM Aceh, Indonezja) jako przyklad wspótpracy z państwami ASEAN, w: Ibidem, s. 114

${ }_{6}$ W. Ostant, ECMM/EUMM Zachodnie Bałkany - sukces czy porażka Unii Europejskiej?, w: Ibidem, s. 143.

7 B. Przybylska-Maszner, Misja doradcza i pomocowa Unii Europejskiej w zakresie reform sektora bezpieczeństwa Demokratycznej Republiki Konga EUSEC RD Congo-uwarunkowania, struktura, efekty, w: Ibidem, s. 147.

8 M. Luszczuk, Misja Unii Europejskiej wspierajaca reformę sektora bezpieczeństwa w Republice Gwinei Bissau, w: Ibidem, s. 182. 
W rozdziale piątym znalazły się artykuły poświęcone misjom UE mającym na celu wspieranie kontroli granicznej w wybranych miejscach na świecie, jako elementu zapewniającego zwiększanie bezpieczeństwa w skali regionu, jak i globu. Jarosław Jańczak poruszył problem misji wspierającej UE dla punktu granicznego w Rafah. Autor wskazał na pozytywny wydźwięk obecności UE, jako struktury postrzeganej przede wszystkim przez Palestyńczyków za neutralna, w procesie pokojowym na Bliskim Wschodzie. Ważne było także wskazanie, obok struktury i sposobu funkcjonowania misji, na skomplikowaną sytuację w rejonie działania, która niejako determinowała skuteczność wszelkich starań podejmowanych przez przedstawicieli UE w Rafah. Zdaniem autora, misja „mogła wspierać określone działania, lecz nie mogła ich zastępować" . Janusz Solak, autor drugiego artykułu zawartego w omawianym rozdziale, odniósł się do unijnej misji wspomagającej działania na rzecz polepszenia kontroli granicznej na styku Mołdawii i Ukrainy. Odnosząc się do działań UE, autor zaprezentował przy tym skomplikowaną sytuację w rejonie, gdzie krzyżują się interesy nie tylko Mołdawii i Ukrainy, ale również quasi państwa, jakim jest Naddniestrze. Zabezpieczenie tego regionu w Europie jest nader ważne dla UE, gdyż obecnie bardzo aktywne są tam grupy przestępcze oraz przemytnicze, oddziaływujące niemalże na cały kontynent w zakresie m.in. kontrabandy czy też handlu bronią. Dlatego, jak napisał autor, „wspólnym zadaniem EUBAM i partnerskich służb mołdawskich i ukraińskich jest stworzenie systemu granicznej i celnej kontroli i ochrony granic, która odpowiadałaby europejskim standardom i zaspokajała prawne potrzeby obywateli każdego kraju"10.

Rozdział szósty w publikacji został oparty na artykułach zawierających opis misji policyjnych UE na terytorium państw znajdujących się w Europie. Anna Potyrała zajęła się kwestią misji policyjnej UE w Bośni i Hercegowinie, która była pierwszą misją tego rodzaju oraz jako pierwsza odnosiła się do działań w ramach Europejskiej Polityki Bezpieczeństwa i Obrony. Autorka zaprezentowała funkcjonowanie misji, która była przedsięwzięciem wielce skomplikowanym, m.in. z racji multinarodowego personelu misji, składającego się z przedstawicieli państw członkowskich UE i państw trzecich, które chciały włączyé się w działania unijne. Jednocześnie same warunki polityczne w Bośni i Hercegowinie, co też czytelnie zostało zaprezentowane w artykule, wymagały od planujących przedsięwzięcia dużego obeznania oraz jasnego formułowania celów stawianych misji UE. Dokonując podsumowania autorka wskazała, że „najistotniejsze dla przyszłości misji policyjnych Unii Europejskiej, w tym dla Misji policyjnej Unii Europejskiej w Bośni i Hercegowinie jest, aby aktywność personelu odzwierciedlała standardy europejskie, nie zaś zasady przyjmowane przez poszczególne państwa członkowskie"11. Drugi artykuł, pochodzący z omawianego rozdziału został poświęcony zagadnieniu misji UE, o nazwie kodowej PROXIMA, która obejmowała obszarem swego działania terytorium Macedonii. Autorki, Monika Izydorczyk i Kornela Oblińska, zaprezentowały czytelnikowi rys sytuacji prowadzącej do uruchomienia operacji UE, a następnie dokonały czytelnej prezentacji struktury oraz sposobu funkcjonowania misji w Macedonii. Interesujące i motywujące do dalszej dyskusji w tym zakresie jest stanowisko autorek wobec zbytniej pobłażliwości UE wobec ludności albańskiej. Rozdział zamyka artykuł Beaty Przybylskiej-Maszner poświęcony także zagadnieniu obecności misji UE w Macedonii. Autorka przedstawiła w nim zagadnienia funkcjonowania niejako kolejnego etapu działań unijnych w tym państwie, w postaci EUPAT, a więc policyjnego zespołu doradczego w Byłej Jugosłowiańskiej Republice Macedonii. Bardzo ciekawe jest zestawienie w ramach jednego wykresu czasookresu funkcjonowania misji i operacji UE w Macedonii, $\mathrm{z}$ jednoczesnym wskazaniem na ich koszta oraz szacunkową liczbę personelu zaangażowanego

9 J. Jańczak, Misja wspierajaca UE dla punktu granicznego Rafah (EUBAM Rafah)-tworzenie podstaw zaufania granicznego w warunkach dlugotrwalego konfliktu, w: Ibidem, s. 194.

10 J. Solak, Graniczna Misja Wspomagajaca Unii Europejskiej w Moldawii $i$ na Ukrainie (EUBAM Moldova/Ukraina), w: Ibidem, s. 200.

11 A. Potyrała, Misja policyjna EUPM w Bośni i Hercegowinie, w: Ibidem, s. 227. 
w działania. Wprowadzenie natomiast na końcu artykułu, w formie załącznika kalendarium wydarzeń w Macedonii, w latach 2001-2008, niezwykle ułatwia zobrazowanie tła działań nie tylko w ramach EUPAT. Odnosząc się do wniosków prezentowanych przez autorkę artykuhu, należy podkreślić problem wczesnego i adekwatnego do potrzeb angażowania się struktur międzynarodowych w rejonach występowania napięć np. na płaszczyźnie etnicznej. Autorka wskazuje, że „,zaangażowanie Unii na tym terenie przyczyniło się w dużej mierze do przywrócenia stabilności na tym obszarze, co doprowadziło ją [Macedonię-J.R.] do chwili, w której coraz bardziej realne są szanse na jej członkostwo w Unii"12.

Ostatni, siódmy, rozdział publikacji w całości został poświęcony także misjom policyjnym UE, jednakże prowadzonym w Azji oraz Afryce. Wojciech Nowiak odniósł się w swym artykule do kwestii funkcjonowania unijnej misji policyjnej na Terytoriach Palestyńskich. Autor stwierdzil, że ,patrząc na rolę Europy należy zauważyć, iż Unia jest jednym z głównych donatorów Procesu Pokojowego, wspierającym możliwość funkcjonowania Autonomii oraz głównym partnerem handlowym Izraela, co skłania do szerszego zaangażowania na rzecz rozwoju i stabilizacji regionu"13. Stąd też, tak cenna jest analiza kreacji i samego funkcjonowania EUPOL COPPS w Autonomii Palestyńskiej. W oparciu o nią można zaobserwować niejako wprowadzenie nowych wymiarów pomocy dla społeczeństwa palestyńskiego, przy jednoczesnym zachowaniu największego atutu UE w kontekście Bliskiego Wschodu, jakim jest postrzeganie przez zwaśnione strony Unii w sposób neutralny. Drugi z artykułów został oparty o obserwację działań misji policyjnej EUPOL w Afganistanie. Autor, Michał M. Kosman, skupił się na zagadnieniu być może obecnie mniej medialnym od działań w ramach ISAF, ale o wielkiej wadze dla budowy państwowości w Afganistanie. EUPOL Afganistan dotyka jednego z najsłabszych ogniw struktur bezpieczeństwa, w postaci formowania i szkolenia afgańskiej policji. Autor z dużą dozą ostrożności i bardzo krytycznie podszedł do przyszłości działań stabilizacyjnych, dostrzegając przy tym istnienie pozytywnych cech obecności UE w Afganistanie. Autorem kolejnych dwóch artykułów, zamieszczonych w siódmym rozdziale publikacji, jest Adam Jaskulski, który poruszył problem misji policyjnych UE prowadzonych w całej Demokratycznej Republice Konga oraz w jego stolicy Kinszasie. Prezentując ogólny rys sytuacji w konfliktogennym środowisku funkcjonującym w DR Konga oraz odnosząc się do kształtu i formy działań podejmowanych tam przez przedstawicieli unijnych misji, autor podkreślił m.in. bardzo ważny mankament związany $\mathrm{z}$ ograniczonym kontyngentem personelu $\mathrm{z}$ UE i państw trzecich zaangażowanych w misje. Kluczowe, chociażby dla wizji przyszłych, podobnych działań UE, jest także zaobserwowane przez autora obniżenie efektywności w związku z różnymi sporami występującymi wewnątrz samej Unii wobec planowania misji policyjnej EUPOL Kinszasa.

Publikację Misje cywilne Unii Europejskiej pod red. Beaty Przybylskiej-Maszner należy ocenić bardzo wysoko, gdyż stanowi ona niezmiernie ważne na polskim rynku wydawniczym kompendium wiedzy o tego rodzaju aktywności UE na arenie międzynarodowej. Układ książki oraz pewna standaryzacja, m.in. w każdorazowym opisie struktury oraz mandatu poszczególnej misji, daje czytelnikowi możliwość porównywania ze sobą konkretnych przypadków. Jednocześnie prezentowane przez autorów różne stanowiska w zakresie poruszanej problematyki, zapewniają krytyczną, a więc ukazującą zarówno sukcesy, jak i porażki, wizję unijnej aktywności w ramach misji cywilnych. Dlatego też omawiana publikacja staje się ważnym głosem w dyskusji nad potrzebą oddziaływania UE w sytuacjach kryzysowych poza granicami państw-członków. Należy także zwrócić uwagę na nasycenie publikacji ułatwiającymi zaznajomienie się

12 B. Przybylska-Maszner, EUPAT-policyjny zespót doradczy w Bylej Jugoslowiańskiej Republice Macedonii, w: Ibidem, s. 254.

${ }^{13}$ W. Nowiak, EUPOL COPPS - Misja Policyjna Unii Europejskiej na Terytoriach Palestyńskich - kreatywnym zaangażowaniem UE $w$ procesie budowy zrębów instytucjonalno-prawnych przyszlego państwa palestyńskiego, w: Ibidem, s. 260. 
z treścią tabelami czy też innymi zestawieniami graficznymi. Każdy kto jest zainteresowany nie tylko problematyką integracji europejskiej czy też stosunkami międzynarodowymi, ale przede wszystkim problemami współczesnego świata powinien zapoznać się z zawartością Misji cywilnych Unii Europejskiej.

JACEK RAUBO

\begin{abstract}
Beata Przybylska-Maszner, Anna Potyrala, Leksykon integracji europejskiej w obszarze Wspólnej Polityki Zagranicznej i Bezpieczeństwa i Europejskiej Polityki Bezpieczeństwa i Obrony, Wydawnictwo Naukowe Wydzialu Nauk Politycznych i Dziennikarstwa Uniwersytetu im. Adama Mickiewicza, Poznań 2009, ss. 312.
\end{abstract}

Wspólna Polityka Zagraniczna i Bezpieczeństwa oraz Europejska Polityka Bezpieczeństwa i Obrony mają kluczowe znaczenie dla Unii Europejskiej, która aspiruje do odgrywania znaczącej roli w stosunkach międzynarodowych. Aktor o zasięgu globalnym musi dysponować instrumentami realizacji własnej polityki $i$ to nie tylko w aspekcie gospodarczym. Promocja stabilności oraz działania na rzecz jej utrzymywania, możliwość skutecznego zmierzenia się z problemami globalnymi, takimi jak: terroryzm, ochrona środowiska, walka z przestępczością międzynarodowa, nielegalną imigracją i handlem narkotykami, to tylko niektóre działania, do których zdolna musi być Unia Europejska. Wiele z nich obejmuje kompetencje państw członkowskich, co nie sprzyja skutecznej realizacji tych ambitnych zadań. Nieudana ratyfikacja Traktatu ustanawiającego Konstytucję dla Europy, zwłaszcza przez Francję, uznana została za sprzeciw wobec głębszej integracji, która wykraczając poza sprawy gospodarcze, oznaczała przejmowanie przez Unię Europejską kolejnych kompetencji państw członkowskich.

Odpowiedzią na potrzeby reformy stał się Traktat lizboński, który wprowadził istotne, choć nie tak odważne zmiany. Utworzono stanowisko Wysokiego Przedstawiciela Unii ds. Zagranicznych i Polityki Bezpieczeństwa, którego kompetencje obejmują zadania realizowane przez Wysokiego Przedstawiciela ds. Wspólnej Polityki Zagranicznej i Bezpieczeństwa oraz Komisarza ds. Zewnętrznych Unii. Formalnie reprezentuje on Unię Europejską na zewnątrz i będzie koordynował jej politykę zagraniczną, jednak fiasko Traktatu Konstytucyjnego zaważyło na unikaniu nazwy Minister Spraw Zagranicznych, co nadmiernie wskazywało na przejmowanie funkcji państwa. Należy również dodać, że Wysoki Przedstawiciel działać może jedynie w oparciu o decyzję podjętą przez wszystkie państwa członkowskie.

Kolejną nowością jest powołanie Europejskiej Służby Działań Zewnętrznych, która będzie korpusem dyplomatycznym Unii Europejskiej. Współdziałając ze służbami dyplomatycznymi państw członkowskich, pod kierownictwem Wysokiego Przedstawiciela, pozwoli to stworzyć silną reprezentację zewnętrzną, która mówiąc jednym głosem w pełni odda aspiracje Unii Europejskiej. Dyskusja dotycząca udziału Polaków w tejże służbie wskazuje na żywe zainteresowanie tą tematyką. Opracowany przez Polski Instytut Spraw Międzynarodowych raport wskazuje, że na 1701 osób zatrudnionych w unijnej dyplomacji, rażąco niska jest liczba przedstawicieli nowych państw członkowskich, w przypadku Polaków wynosi ona zaledwie $36^{1}$. Jednak oczeki-

R. Formuszewicz, J. Kumoch, Analiza obsady stanowisk szefów delegatur Unii Europejskiej w przededniu powolania Europejskiej Sluzby Dzialań Zewnętrznych, Warszawa 2010, s. 9. http://www.pism.pl/zalaczniki/PISM_Raport_ESDZ.pdf, wyświetlono 4 października 2010. 